\title{
Big Book as an Effort to Increase Beginning Reading in SD Negeri Percobaan, Medan City
}

\author{
Laily Sa'idah $^{1}$, Isda Pramuniati², Evi Eviyanti ${ }^{2}$ \\ ${ }^{1}$ Postgraduate Students at State University of Medan, Indonesia \\ ${ }^{2}$ Postgraduate Lecturer at State University of Medan, Indonesia \\ misslelyadeeva@gmail.com
}

\section{Abstract}

This research elaborates the material development of beginning reading for students Grade II SD Negeri Percobaan Medan through Big Book Media. The method of the research is Research and Development $(R \& D)$ which consists of 10 steps of research, namely (1) potential and problems, (2) data collection, (3) product design, (4) design validation, (5) design revision, (6) product testing, (7) product revisions, (8) usage trials, (9) product revisions and, (10) mass production. This research was conducted at SD Negeri Percobaan Medan Medan Baru District held in the odd semester of the 2017/2018 academic year. The research was carried out on Indonesian language learning by using Big Book media. The results obtained in this study show that the teaching materials are appropriate and valid for using by Grade II primary school students because they have been assessed and validated from the expert team. This conclusion was taken based on the results of the analysis of experts consisting of grammar experts in fairly decent qualifications (82\%), material content experts were in very decent qualifications (94\%) and learning design experts were in decent qualifications (73\%). From all validator assessments, there were sufficient qualifications with an average value of $83 \%$. This is reinforced by the results at the product trial stage obtained a percentage of $53.33 \%$ and the trial phase of use obtained a percentage of $86.66 \%$. This means that indicators of effectiveness have been fulfilled. So with the results obtained it can be stated that the development material is appropriate to be used in Grade II $S D$ Negeri Percobaan in order to improve reading skills in the implementation of a better learning process.
Keywords

big book media; student learning outcomes;

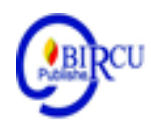

\section{Introduction}

Education is a conscious and planned effort to create an atmosphere of learning and learning process so that students actively develop their potential to have spiritual spiritual strength, self-control, personality, intelligence, noble character, and the skills needed by themselves, the community, the nation, and the State

One of the important messages in education contained in the 2003 National Education System Law in Chapter III article 4 paragraph 4 concerning the principles of education stated that "education is carried out by developing a culture of reading, writing and arithmetic for all citizens". Broadly speaking, the verse explains that reading for the community is very important. Therefore learning to read must also be carried out in accordance with the principles of education. 
Reading occupies an important role in the context of human education, especially in the current era of globalization, information and communication. This is because reading is a bridge for anyone who wishes to achieve progress and success both in the education and employment environment. "Through reading, a person can gain new experiences beyond the limits of space and time." By reading someone will obtain information for the purposes of science, technology, art and culture "(Subadiyono, 2011: 9).

Reading in elementary school students plays an important role in learning success. Reading to elementary students needs to be taught carefully because it is related to reading at more complex stages. "The goal that can be achieved through teaching reading is to develop moral values, the ability to reason, and creativity" (Akhadiah, 1999: 29).

Students in Indonesia still have a low average reading ability compared to other countries. The research was conducted by the International Association for The Evaluation of Educational Achievement in 2006 which stated that of 45 countries in 3 worlds, Indonesia was ranked 41 or number four from the bottom (litbang.kemdikbud.go.id). This is because in general people use their time to read no more than $1 \%$ in a day, it is also limited when receiving lessons in school or just reading titles in the newspaper without reading the contents as a whole. "This also happens to children of primary school age who basically have more dominant play activities every day" (Prasetyo, 2008: 14).

The results of the ability to learn to read the beginning of class II students of SD Negeri Medan Experiment obtained average results, class II students totaling 60 people can read 60 words per minute of common words separately, and 65 words per minute of related words with a piece of writing, however the level of understanding is only $40 \%$, students do not understand what they are reading (Data taken from grade II teachers in 2016). Only 20 of them are able to understand writing well, i.e. those who read at a satisfactory level. In addition, many children have difficulty understanding the spoken Indonesian.

\subsection{Big Book}

\section{Review of Literature}

Big books are reading books that have large sizes, writing, and images. Big Book sizes can vary, for example A3 size, A4 size, A5 size or the size of a newspaper. The size of the Big Book must take into account the readability of all students in the class. According to Yuniati, (2014: 33) Big Book can be a strong motivation to learn about the pronunciation of words, forms, and types of compound words, verbs, abbreviations, and poems. Children's habits in listening to stories and reading will increase children's vocabulary so that children more easily understand the words that are in the Big Book. Big Book according to Harimurti (2010: 4) is a picture book that was chosen to be raised because it has a "special quality". Specific qualities according to Harimurti (2010: 4) are: a. involves the child's interest quickly because of the image he has, b. contain interesting rhythms, c. have a big picture, $d$. there is a repeated writing, e. the plot is simple and clear, and f. often incorporates an element of humor. This large book is usually used for children in the early grades. Inside the Big Book contains a short story with a simple sentence with large writing given a colorful picture. Yuniati (2014: 51) said that Big Book is one of the media that children love and can be made by teachers. From the explanation above, it can be concluded that Big Book is a medium in the form of a large printed book to teach students to learn the pronunciation of words, forms and types of words that contain pictures and short stories. 


\subsection{Benefits of Big Book Media}

Big Book is a large story book with colorful pictures so it can attract students to read and simple stories and students use to learn to read and add vocabulary. Mohana (1999: 5) mentions some of the advantages of using Big Book, which is as follows: Because Big Books are large, students can see pictures of the storyline clearly, such as when they read books themselves. This certainly will be interesting for students. Big Book makes students become more focused on reading material and also the teacher. Usually if the teacher uses an ordinary book, students will be engrossed in playing by themselves. However, with Big Book students will be interested and willing to listen to stories from the teacher. Students will understand and comprehend the contents of stories in the Big Book rather than ordinary reading books because the words contained in the Big Book are simple words. Students can follow every word spoken by the teacher and know how it is written. Big Book facilitates students as if they were directly watching the story the teacher was reading. Students can feel the course of the story, and. Big Book is a new thing that will make students interested and have a high curiosity about what is in it. So students become enthusiastic in learning. Colville, (2006: 493) explains the characteristics of the Big Book, namely: a) about 10-15 pages of short stories that involve the interests of students so they are interested, b) patterned so that students are easy to learn and easy to remember, c) large images help students construct meaning from the story, d) contain phrases that are repeated and contain vocabulary that matches the student's vocabulary, e) simple, but interesting in the storyline, and f) contains elements of humor.

\subsection{Steps for using the Big Book}

There are several steps put forward by experts regarding the use of Big Book teaching materials, including Colville (2006: 497) describing the steps of learning to use Big Book: 1. a teacher who makes his own Big Book can make a story that will be written into the Big Book. The story is a simple story that is suitable for grade I elementary school. It can also be a story that is well-known to students so they better understand the course of the story, 2 . after making a story, the teacher can use poster paper, manila, cardboard and cardboard for the front. Big Book is a large book, so teachers must draw story patterns on large paper, 3 . The teacher describes a series of stories on paper. You can also attach clip art or pieces of image from a used magazine. The picture on the front can be covered with patchwork to make it look like a thick fairy tale book. Paper that has been drawn is then put together with a spiral or ordinary bond so that it is easy to flip through, 4. when the Big Book is used for teaching, the teacher first shows the front cover and makes students have high curiosity. The teacher can ask questions about what students observe on the cover of the Big Book. Students then bring up their opinions with simple words. The teacher continues to lure students so that their curiosity increases and can focus on the lesson. The teacher can write on the board the predictions from students about the contents of the story in the Big Book, 5. Next, the teacher starts reading the title and the name of the author to add predictions from students. It aims to make the classroom look familiar with open responses. The teacher also links the knowledge students have with the title Big Book, 6. The teacher starts to read the story aloud and expressively so students can focus on the story. The teacher also shows a picture illustrating the story so students know exactly how to describe the story. Students listen without interrupting until the end of the story, 7. The teacher asks how the contents of the story he has read are interesting or not. Students begin to express their reactions, 8. The teacher invites students to read together aloud classically. The teacher points to every word that is read, 9 . The teacher asks students to read stories in groups so that students really understand the 
contents of the story, 10. The teacher appoints students one by one to read. Reading repeatedly can improve student skills, and 11 . The teacher develops students' reading skills to see whether students know what content they are reading or not. The usual thing to do in development activities is to retell the contents of the story being read

\section{Research Method}

This type of research is research and development (Research and Development R\&D). Research and development is carried out to produce products. The product that will be produced in this research development is the Class II Reading Comprehension teaching material on the subject III theme "My Daily Tasks"

This research was conducted in Medan Experiment Elementary School, Medan Baru Subdistrict, with the object of research in class IIa and IIb, this study was conducted in odd semester of the academic year 2017/2018.

This research uses Research and Development (R\&D). According to Sugiyono (2013: 409) there are 10 steps in using the Research and Development (R\&D) research model, namely: (1) potential and problems, (2) data collection, (3) product design, (4) design validation, (5) revision design, (6) product trials, (7) product revisions, (8) product trials, (9) product revisions and, (10) mass production. The steps in using the Research and Development $(R \& D)$ method are shown in the following figure:

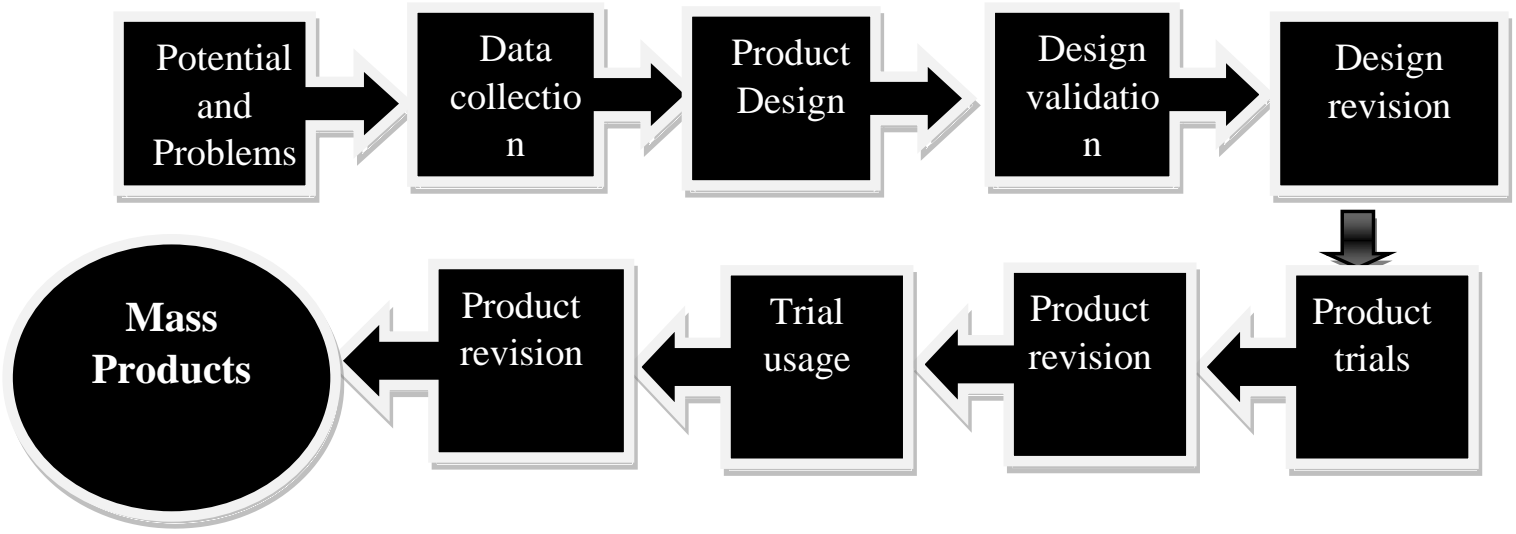

Steps of the Research and Development Method

a. Potential and problems R\&D can depart from the potential and problems. In this first step the researcher made observations to the Medan Experiment State Elementary School, as a place to be the object of research by the researcher. gathering potentials and problems in research is a basic thing that must be done by researchers because this is where researchers see things that are a problem so this phenomenon must be examined.

b. Collecting Data In this step the researcher collects data, which can then be used as material for planning. In this case the researchers conducted data collection through direct observation to the school and retrieve data from teachers related to reading at the school.

c. Product design In this case researchers began to make teaching materials and determine its components. Before making teaching materials, there are some preparations that are made, namely preparing materials needed in making teaching materials such as paper for drawing, pencils, colored pencils or crayons. Then adjust the learning design with themes and sub-themes. After adjusting, drawings are made according to the story, then colored so the images look more attractive. As a reference 
taken from sources that can be accounted for such as books, journals and others that can support the process of making teaching materials.

d. Design validation After the media is created, researchers provide teaching materials to the validator to make an assessment as a way to validate teaching materials whether or not the instructional materials are used properly. Validation tests are carried out to determine whether or not a product is developed to be used as teaching material in schools. Validation can be done by researchers inviting validators representing field experts to assess and solicit their opinions on the appropriateness of the contents of the material, the feasibility of the learning design, and the appropriateness of the language that has been developed and will be trialled. If the expert judgment still needs revision, then the product developed must be revised until it is declared valid by the experts. Components validated by experts include the appropriateness of the contents of the material, the appropriateness of the presentation, and the appropriateness of the language.

e. Design revisions

After evaluating the validator, of course there are weaknesses and strengths of the design of the first teaching material made, then in this process revisions are made to the improvement by the researchers according to the input and suggestions from the validator team so that the teaching material produced can be used as expected.

f. Product trials

In this case the product was tested on research subjects, namely students in class IIa of SD Negeri Medan Experiment. In this step the questionnaire is also used as a data collection about the teaching material that is developed. Questionnaires were distributed to class IIa students and students filled out the questionnaire so that the results of the questionnaire could be identified as weaknesses and deficiencies in teaching materials. Activities at this stage are carried out with individual trials at Medan Experiment Elementary Schools to obtain initial input on specific products or designs. Students who were subjected in the individual trials were 1-3 IIa elementary school students randomly selected, consisting of 1 high ability student, 1 moderate ability student, and 1 low ability student. After individual trials, the product or design is revised.

g. Product revision

After getting weaknesses and lack of teaching materials in accordance with the results of the previous trial questionnaire, the researcher revised the revision according to the weaknesses and deficiencies obtained.

h. Trial usage

In this test Big Book media teaching materials are used in the teaching and learning process in Medan Experiment Elementary School in class IIb, students will be taught how to read the correct understanding by the teacher by using Big Book media on the theme "My Daily Tasks". Activities at this stage involve the subject broadly, namely all students in the class. The main objectives of this stage are to find out: (1) determine the effectiveness of changes made based on evaluations of product trials and identify problems that may be experienced by learners. (2) the feasibility of Indonesian teaching materials based on student assessment. The results of this small group trial are used to make product or design revisions. 
i. Product revision

After testing the use of Big Book teaching materials in the teaching and learning process, the researcher needs to revise the product deficiencies in accordance with the suggestions and input from the validator obtained during the application of this teaching material.

j. Mass products

After all stages have been carried out, the researcher can publish the final results of the teaching material developed based on the validation, revision, and product tests that have been carried out and if the results show a positive number the researcher can recommend that this teaching material be a teaching material for grade II elementary school students .

\section{Disucssion}

The final goal of this research is to produce a product that is valid and effective for use. The final product developed in this study is the Big Book grade II elementary school with the theme III subject " Tugasku Sehari-hari".

The product development process in this study uses the Research and Development (R\&D) development model. According to Sugiyono (2013: 409) there are 10 steps in using the Research and Development (R\&D) research model, namely: (1) potential and problems, (2) data collection, (3) product design, (4) design validation, (5) revision design, (6) product trials, (7) product revisions, (8) product trials, (9) product revisions and, (10) mass production. The first thing to do is that this first step the researcher made observations to the Medan Experiment State Elementary School, as a place that was made the object of research by the researcher and collected potentials and problems.

After seeing the potential and problems then the research continues at the data collection stage which can then be used as material for planning. In this case the researchers conducted data collection through direct observation to the school and retrieve data from teachers related to reading at the school.

After making observations and all the data collected, the next step taken by the researchers is to design the product design. With the initial preparation of preparing the materials needed in making teaching materials such as paper for drawing, pencils, colored pencils or crayons. Then adjust the learning design with themes and sub-themes. After adjusting, drawings are made according to the story, then colored so the images look more attractive. As a reference taken from sources that can be accounted for such as books and others that can support the process of making teaching materials.

After the product is designed, the next step is the researcher submits the product to the expert team to be validated to find out whether the product is suitable for use or not. This product evaluation was carried out by 3 expert teams namely in the field of grammar eligibility namely by Prof. Dr. Khairil Ansari, M.Pd, in the field of material eligibility, namely by Dr. Wisman Hadi, M.Hum and the feasibility of learning design, namely by Dr. Zuklkifli, M.Sn.

In the Big Book media development activities after the completion of the design, the Big Book media is then submitted to the expert team to be assessed and given suggestions for improvement. After being declared valid then the Big Book media is tested on students. Product testing is carried out in one school consisting of 2 classes. The first product test or product trial phase is in class IIa with a total of 30 students. Based on product trials, 16 
students (53.33\%) achieved mastery learning and 14 students (46.67\%) did not achieve mastery learning. This means that classically has not met the achievement of students' mastery learning as a whole class.

After conducting the first trial and revising the product, the next step is the second trial or trial use of class IIb with 30 students. Based on product trials, 26 students $(86.66 \%)$ achieved mastery learning and 4 students $(13.34 \%)$ did not achieve mastery learning. Thus it can be concluded that the Big Book media produced has been effective for use in learning activities.

From the results of the research above, it can be concluded that the use of Big Book media in learning the subject III theme "Tugas Sehari-hari" can improve students' reading comprehension. This is reinforced by the classical completeness level data in the trial use in class IIb of $86.66 \%$.

\section{Conclusion}

Conclusions that can be taken are based on the results of a study of the results of the research and discussion in the previous chapter, including:

a. Through several stages and a series of product trials on the development of teaching materials and reviewed from students as users, Big Book media can improve students' understanding of the content of the reading. Using Big Book media has achieved minimal compatibility criteria. This means that the Big Book media can be used in the second grade students of SD Negeri Experimental Medan to improve reading comprehension in the process of implementing better learning.

b. The results of the validity of teaching materials including into the category are appropriate and valid for use by grade II elementary students because they have gone through the assessment and validation of the expert team. This conclusion is based on the results of the analysis of experts consisting of grammar experts who are in a fairly decent qualification (82\%), material content experts are in very decent qualifications (94\%) and learning design experts are in decent qualifications (73\%).

\section{References}

Abbas, Shaleh. 2006. Pembelajaran Bahasa Indonesia yang Efektif di Sekolah

Adi, Prasetyo. 2008. "Pemanfaatan Grey Literature di Perpustakaan". Jurnal Media Informasi dan Komunikasi Kepustakawanan: Buletin Perpustakaan Universitas Airlangga. Vol.III,No.2, edisi Juli - Desember

Adi, Prasetyo. 2008. "Pemanfaatan Grey Literature di Perpustakaan". Jurnal Media Informasi dan Komunikasi Kepustakawanan : Buletin Perpustakaan Universitas Airlangga. Vol.III,No.2, edisi Juli - Desember

Akhadiah, Sabarti, dkk. 1999. Bahasa Indonesia 1. Jakarta: Depdikbud Aksara

Anwar, Sutoyo. 2009. Pemahaman individu, observasi, checklist, interview, kuisioner dan sosiometri. Yogyakarta : Pustaka Pelajar

Burns, P. C. ,Roe, B. D dan Ross, E.P. 2004. Teaching reading in today's elementary schools. Boston: Houghton Miffiliin Company.

Cahyani, Isah. 2011. Pembelajaran Bahasa Indonesia, Jakarta : Rineka Cipta

Colville, Hall, Susan \& Oconnor, Barbara. (2006). Using Big Book: A Standars-Based Instructional Approach for Foreign Language Teacher Candidate in a Prek-12 Program. 